INTERNATIONAL JOURNAL FOR

HISTORY, CULTURE AND MODERNITY

www.history-culture-modernity.org

Published by: Uopen Journals

Copyright: @ The Author(s).

Content is licensed under a Creative Commons Attribution 4.0 International Licence

elSSN: 2213-0624

\title{
For the Nation and the World: Malcolm Cowley, the Making of American Literature and the Cultural Cold War
}

Hans Bak

HCM 7: 1008-1037

DOI: $10.18352 / \mathrm{hcm} .596$

\begin{abstract}
In this essay I examine the extent to which Malcolm Cowley's mid-century efforts on behalf of 'the making of American literature' - as critic, editor, publisher's advisor and literary gatekeeper - dovetailed with the aims of U.S. cultural diplomacy and (wittingly or unwittingly) played a part in the 'cultural Cold War'. I analyze in particular 'American Books Abroad', Cowley's concluding chapter to Literary History of the United States (1948), and examine his role as guest editor and critic of the Autumn I953 issue of Perspectives USA, a quarterly launched by James Laughlin of New Directions and funded by the Ford Foundation. The latter aimed to correct a widespread European perception of American culture as imperialist and steeped in mass entertainment, by demonstrating it was at least as highbrow and distinguished as the best of Europe - and an effective beacon of individual freedom against totalitarian communism.
\end{abstract}

Keywords: American literature, Cold War modernism, cultural diplomacy, Malcolm Cowley, Perspectives USA

\section{Introduction}

For much of the 'American Century' - most centrally from the I930s to the mid-I960s - Malcolm Cowley (I898-I989) was an influential 
critic, historian and literary gatekeeper who helped to forge a literary canon for Cold War America. Through books like Exile's Return (I934; rev. ed. 195I) and The Literary Situation (1954), and numerous published essays and book reviews, he practised a mode of criticism that was sensitive to the social, historical, economic and biographical context of literary and cultural production, thus helping to lay the foundations for post-war 'American Studies'. ${ }^{I}$ From his public platform as literary editor of The New Republic in the radical I930s, Cowley spoke out authoritatively on matters of literature and politics, struggling to maintain his critical independence while practising what Alfred Kazin insidiously called 'a sophisticated literary Stalinism'² and apprehensively following the advance of international fascism in Europe as war loomed with mounting inevitability. After his abdication as the magazine's editor, ${ }^{3}$ in the early I 940 os he definitively broke with the radical politics he had embraced through the I930s, and committed himself to the American war effort by accepting an invitation from Archibald MacLeish to join the Office of Facts and Figures (precursor of the Office of War Information) in Washington, D.C., only to find himself ousted from his position as Chief Information Analyst by Congressman Martin Dies, who on the floor of Congress denounced his earlier affiliations with communism. Cowley thus became one of the earliest victims of the counterrevolutionary purge that soared under Joseph McCarthy after the war. Pained, he withdrew from politics, re-embraced literature, and set out to re-establish himself as an influential literary historian and shaper of literary opinion. Though his radical politics continued to haunt him through the Cold War years, he now fully committed himself to chronicling the literary achievements of contemporary American writers and establishing a sense of an American literary past, for the nation and the world.

Working at the intersection of literary journalism, criticism, editing, publishing and teaching, from the early I 940 S Cowley consciously set out to realize such aims through authoritative reappraisals of "classic' writers like Frost, James, Whitman and Hawthorne, through corrective revaluations of Hemingway and Faulkner in Viking Portables ( I944; I946), and through his contributions to Literary History of the United States (1948), in particular its concluding chapter 'American Books Abroad'. In the early I950s he participated (as critic and editor) in Perspectives USA, a quarterly launched by James Laughlin of 
New Directions and funded by the Ford Foundation, which aimed to correct a widespread European perception of American culture as imperialist and steeped in mass entertainment, by demonstrating it was at least as highbrow and distinguished as the best of Europe - and an effective beacon of individual freedom against totalitarian communism.

In this essay I aim to examine the extent to which Cowley's efforts for Literary History of the United States and for Perspectives USA, informed by a cosmopolitan ideal of international modernism and distrust of the nationalist ethos marking the U.S. in the early Cold War years, dovetailed with the aims of U.S. cultural diplomacy and (wittingly or unwittingly) played its part in what Frances Stonor Saunders has called the 'cultural Cold War', ${ }^{4}$ and what Greg Barnhisel has defined as 'the Cold War modernist project'. Cowley's efforts to define and shape a canon of American literature must be understood in the context of a nationwide effort - supported by government policy and institutions (from the war-time Office of War Information to the United States Information Agency, launched in I953), private foundations (the Rockefeller and Ford Foundations) and non-aligned initiatives (publishers, magazines, the Congress for Cultural Freedom, the Voice of America) - to project an image and understanding of 'America' and American literature and culture that fitted the cultural and political aims of Cold War cultural diplomacy under Truman and Eisenhower: to make sure America was understood both at home and abroad as a beacon of freedom and democracy, in opposition to the totalitarianism and oppression that marked life and culture under Soviet Communism. ${ }^{5}$

\section{For the Nation and the World: Cowley and the Canon in the Cultural Cold War}

Cowley was ideally equipped for such a task. As a 'worker at the writer's trade' he aimed to be an influential 'mediator between serious writers and the public', who cherished 'the I 8 th century ambition to write for the intelligent but unspecialized reader'. ${ }^{6}$ Straddling the various fields of highbrow criticism, middlebrow journalism, teaching and publishing, he sought to protect and enhance standards of professional authorship and book culture. Through his work for the League of 
American Writers, the artists' colony Yaddo, and the National Institute and American Academy of Arts and Letters, he hoped to foster a democratic community of culture. Cowley's efforts to enhance the appreciation for American writers, both at home and abroad, were marked by a cosmopolitan orientation that was shaped by his World War I experiences as an American Field Service volunteer in France, his expatriate years in Montpellier, Paris and Giverny in the early I920s, and the central position he occupied in American literary and cultural life in the I930s, when the fate of American democratic culture became increasingly intertwined with global affairs. An ardent fellow traveller, he kept a close eye (as close as radio or journalism allowed) on what was happening in the Soviet Union. From his strategic position as New Republic editor, he saw both the national and the international scene move across his desk, through newspaper accounts, in editorial meetings, through contacts with authors from the U.S. and Europe, in visits to Depressionridden America (as in 1932 to the striking miners in Harlan County, Kentucky) and, in I937, to France and Spain, to report on the Spanish Civil War. It was the Fall of France in May I940 more than anything else that pushed him off the Moscow Express, and through the war years he continued to follow, with concern and trepidation, the fate of international literary friends like Louis Aragon. Though Cowley's internationalist orientation was circumscribed - his gaze was mostly directed east, towards the Europe he knew from personal experience ${ }^{7}$ - it nonetheless helped him maintain a sense of comparative cultural relativity: he never claimed too much for the writers of his generation, or, when measured by transnational standards, for the achievement of American writers at large.

Cowley's mid-century efforts to forge an American canon took place at the intersection of the national and the global. As Kristin L. Matthews and Greg Barnhisel have argued, ${ }^{8}$ as the United States emerged from World War II in a new position of global leadership, it found itself facing new challenges, uncertainties and confusions, on both the home front and the international scene. Critic Howard Mumford Jones noted a 'deep-seated anxiety to comprehend the responsibility of our culture in the world' ${ }^{9}$ Kristin Matthews has demonstrated how on the 'rhetorical battlefront' of the early Cold War America's new position of world leadership triggered an intensified engagement with questions of self-definition - of 'America', of American citizenship, of American 
literature and culture - and engendered a widespread conviction that reading was 'a way in which Americans could prepare themselves to become responsible citizens of a global superpower' ${ }^{\text {Io }}$ The freedom to read implied the responsibility to read well, and through reading to become a critically informed citizen of a free democracy. Such critical and creative readers, was the implied political signal, could only exist in a free democracy like the United States; they were anathema in a totalitarian, oppressive society under Soviet communism. By embracing the ideal of reading critically and responsibly, moreover, Americans would diminish their vulnerability to communist ideological infiltration, and thus enhance the national security. Through the Cold War years government officials, book clubs, educators, publishers and public intellectuals proclaimed the strategic connection between reading and democratic citizenship: reading well was 'a civic duty' ${ }^{I I}$ and books, as Franklin Delano Roosevelt had proclaimed during World War II, were 'weapons' in 'man's eternal fight against tyranny'. ${ }^{\text {I2 }}$

One of the nation's leading literary and cultural commentators, Cowley was persistently concerned with the status of reading in America, ${ }^{13}$ and through the early Cold War years grew increasingly disturbed by the declining reading skills of the nation's youth. Though during and immediately after the war reading had soared, partly through the Armed Services Editions, an initiative of the Council for Books in Wartime, and the G.I. Bill, ${ }^{14}$ by I 954 Cowley held a more negative view. As he observed to Gilbert Harrison, then editor of The New Republic, on I4 October I954: 'The biggest threat [to a vigorous and creative American literature, and, thus, a functioning democratic culture] is the decline of the reading habit, owing partly to TV but chiefly to the collapse of secondary education - high school students aren't learning how to read: they graduate without having read one complete book'. ${ }^{\text {I5 }}$

Such concerns also undergirded Cowley's engagement with the U.S. book trade, the standards governing the profession and business of publishing. As Trysh Travis reminds us, besides being an influential critic and editor, Cowley also held 'close and formal ties' to the field of trade book publishing, and recurrently wrote on 'the literary business' ${ }^{16}$ The fate of books, authors and the reading public was intimately interconnected with the health of the state of U.S. publishing. Both for Cowley were indispensable tools in forging a free democratic culture, and in holding at bay the 'dangers' to American writing that 
he envisioned ${ }^{17}$ - the decline of reading, the rise of mass culture, the commercialization of the book industry, the mounting timidity and conformism of the Cold War years.

In the I940s such beliefs - and the need to secure an income as a freelance writer - drew him into the orbit of Harold Guinzburg's idealistic vision for Viking Press. After he had produced three Portables for Viking under the auspices of a five-year Mellon Foundation grant - on Hemingway (I944), Faulkner (I946) and Hawthorne (I948) - in I949, when the Mellon money expired, he entered into a part-time contract with Viking Press as advisory editor and literary scout. Bearing special responsibility for the Portable series, he could thus make common cause with those who believed that, as Travis has observed, 'bookmen bore a special responsibility to their nation as stewards of cultural democracy', even as he 'remained somewhat skeptical of the publishing industry's ringing claims'.$^{18}$ The ideal of cultural stewardship was taken seriously by Viking's founding father Harold K. Guinzburg. Guinzburg, who during the war had headed the London Publications Division of the Office of War Information and after the war founded the Committee on Reading Development, steered Viking Press along his personal politics of progressive liberalism and drew most of his employees into its orbit; at Viking, in Travis's words, 'publishing meant an opportunity - an obligation, even to promote democracy through the special agency of the printed word'. ${ }^{19}$

Modelled on the Armed Services Editions (Viking editor Marshall Best had served on the Council for Books in Wartime), the Viking Portable series, launched in I943, aimed at soldiers and home-front readers alike. By the time of Cowley's Portable Faulkner (I946), the series was 'recognized as one of the industry's wartime success stories'.$^{20}$ When, shortly after, as a result of the G.I. Bill, the college market began to boom, Cowley - who for several years had been supplementing his income as a roving academic lecturer - was welcomed into the Viking flock as the firm's literary scout for the expanding college market. Cowley could thus hope to realize his ambitions for American literature by bridging his various fields of professional activity: as a critic and historian of (modern) American literature, chronicler and steward of the writing profession, confidant and advocate of young writers, editor, publisher's advisor, and academic teacher.

Cowley's cosmopolitan orientation made him sceptical, even exasperated, about the nationalist ethos marking the U.S. in the early 
Cold War years. In letters and essays he criticized a nationalism which urged writers to present a polished image of 'America the So Beautiful' and demanded that they close their eyes to injustice, social suffering, or even vulgarity; in such a 'mood of patriotic caution', he thought, mere 'candor about ourselves' stood in danger of being branded as 'disloyalty'. ${ }^{21}$ In revaluations of older writers, too, Cowley warned against 'a narrow nationalism that has spread from politics into literature' and which demanded that American writing should be 'affirmative, optimistic, not too critical, and "truly of this nation". ${ }^{22}$

Alternatively, Cowley saw in Hawthorne the precursor of a national literary tradition that was not primarily democratic, optimistic, epic or realistic, but rather subjectivist, psychological, lyrical and symbolic. F.O. Matthiessen's American Renaissance (I94I), though focused on the literary giants of the nineteenth century, Cowley felt, also shed important new light on the literature of the present: 'Why is it', he wrote Matthiessen on 24 July I944, 'that most of the good American novelists and poets are "haunted" writers; and why is it that, even if they begin as naturalists, they end essentially as Symbolists?' ${ }^{23}$ Cowley's new perspective informed his influential Portable Hemingway (I944), which corrected the then current view of Hemingway as a tough-guy naturalist writer and presented him instead as spiritually akin to Poe, Hawthorne and Melville, 'the haunted and nocturnal writers, the men who dealt in images that were symbols of an inner world' ${ }^{24}$

Both The Portable Hemingway and, even more so, The Portable Faulkner (I946) were part of Cowley's efforts in the I940s to connect the writers of his generation to the classic writers of the past. But his forging of a new understanding of an American literary tradition also must be understood in the context of Cowley's evolving career, and of the cultural-political work of American literature in the context of Cold War cultural diplomacy. The Portable Faulkner famously boosted the reputation of Faulkner - indirectly leading to the Nobel Prize - and in the process served to rehabilitate Cowley himself: in the same year, I949, that Faulkner received the Nobel Prize, Cowley was elected to the National Institute of Arts and Letters. Cowley's Portable helped to establish a new understanding of Faulkner as not a regionalist but a great modernist whose work carried universal implications for a postwar world in moral and spiritual crisis. Cowley read Faulkner in part from his own needs and preoccupations - Faulkner, after all, reaffirmed 
precisely the human values ('love and honor and pity and pride and compassion and sacrifice', as he put it in his Nobel Prize speech ${ }^{25}$ ) which Cowley had come to feel were lacking in the reductive communist understanding of man; moreover, unlike Cowley himself, he had remained unblemished in the political I930s.

In Cowley's appreciation Faulkner could thus grow into a moral author with an incorruptible artistic integrity, a sharp and panoramic understanding of the impact of history on collective and individual consciousness, and an unsurpassed depth of imagination..$^{26}$ In effect, the personal needs of the critic coincided with the cultural historical moment to make the upgrading of Faulkner possible. As Lawrence H. Schwartz has argued, Faulkner was precisely the great writer with universal significance the U.S. needed to culturally and morally legitimize its post-war position of political and economic power in a Cold War world. ${ }^{27}$ Following in Schwartz's footsteps, Greg Barnhisel has credited Cowley with beginning 'the redefinition of Faulkner', which was subsequently taken up and accelerated by the New Critics and the New York Intellectuals, a conjunction of 'literary elitism and liberal anti-Communism'. In the wake of his Nobel Prize speech - which Barnhisel argues 'intersected obliquely' with Truman's Campaign of Truth - Faulkner became 'the most significant figure in the exportation of American modernism to the rest of the world'. Indeed, after conquering an initial reluctance, Faulkner showed himself 'an obliging participant in the American cultural-diplomatic program, travelling abroad frequently on behalf of the USIA' - to Brazil, Japan, Greece, as well as colleges in the United States. ${ }^{28}$ As such, even if Cowley could not see it in quite this way, ${ }^{29}$ The Portable Faulkner dovetailed with U.S. Cold War cultural diplomacy and the endeavour to establish a national American literature which could be a bulwark against the totalitarian communist East, and which culminated in the Literary History of the United States ( I948).

\section{For the Nation and the World: American Studies and Literary History of the United States}

Both the emergence of the field of American Studies, which originated in the I930s but firmly took root in American universities in the postwar years, and the forging of a national tradition of American literature, 
which crystallized into the Literary History of the United States, need to be understood in the context of America's new position as leader of the free democratic West and the attendant Cold War cultural diplomacy.

Tremaine McDowell's American Studies (1948) offered a pragmatic definition of the new interdisciplinary field of American Studies as rooted in a vision of national unity-in-diversity, American exceptionalism and internationalism. Turning against the aesthetic-formalist approach of the then dominant New Criticism, it emphasized the need for an interdisciplinary conjunction of the humanities (history and literature) and the social and political sciences, so as to develop a synthetic understanding of 'our national culture'. ${ }^{30}$ McDowell also placed American Studies in an international, if mostly Euro-American, perspective: American culture, he reasoned, was a 'fresh and new fortunate' synthesis of many European cultures and not merely an AngloAmerican amalgam. Moreover, U.S. post-war world leadership had brought the world to 'our doorstep' and thus the study of U.S. culture had become a supranational affair: 'The study of American culture is, then, a microcosmic examination of European culture as well as a macrocosmic examination of regional society'. ${ }^{31}$ In I 948 McDowell understood such internationalism mostly as the projection of an American cultural model of unity-in-diversity on the world. The mission of American Studies thus accorded perfectly with U.S. cultural diplomacy under Truman and Eisenhower. Precisely because 'America' could be a blueprint for the world, critical understanding of the national culture was a prerequisite for a new international world order: 'an enlightened American nationality is one of the essentials to an effective league of mankind. Self-knowledge is therefore prerequisite to citizenship both in the United States and in a world community'. ${ }^{32}$

A similar emphasis on national unity-in-diversity, exceptionalism and internationalism informed the 1948 Literary History of the United States, supervised by Robert E. Spiller, which would determine the image of the genesis and growth of American writing, for the U.S. and Europe, at least into the I96os. It presented a flamboyant version of the American canon and literary history resting on pioneering studies like Matthiessen's American Renaissance (I94I) and Kazin's On Native Grounds (1942), and aimed to give scholarly legitimation to the enhanced international standing of the literature and culture of the new world power, and to underwrite symbolically America's status as 
bulwark of the free democratic West against the communist East. On the one hand, the LHUS, begun in I $938,{ }^{33}$ was fed by the revaluation of the American scene and the American character which emerged from the economic and political crises of the I930s. On the other hand, this 'experience of national self-discovery' ${ }^{34}$ received a strong impulse from the international crisis situation, in which the U.S. had become treasury and guardian of Western culture in a world facing the threats of fascism and totalitarian communism. LHUS's preface defined American literature emphatically as the highest aesthetic and moral expression of unique and exceptional American values, the embodiment of national unity and an independent American tradition. In Cowley's ironic words, the symposium was 'a mass demonstration of pride in American writing, as if the fifty-five scholarly contributors had marched down Fifth Avenue behind a brass band'. ${ }^{35}$ Yet, like McDowell in his American Studies, the LHUS affirmed that it was the specific character of American literature - democratic, individualistic, optimistic, humanitarian - which made it into a possible model for the world of the future.

\section{'American Books Abroad'}

Cowley's reputation received an important boost from his participation in the prestigious LHUS, to which he contributed three chapters. ${ }^{36} \mathrm{On}$ 2I February 1945, upon learning that its final chapter was to deal with the changed international standing of American literature, Cowley had enthusiastically written to Spiller:

Now I think you' re really talking about the final chapter of the History. That's a subject on which something can be said - imagine, for example, the contrast in a few years between Eliot's going to England in I9I4 and Auden's coming to America in 1938 , both to find a milieu in which they could write. Or the fact that James and Twain, our two best writers of their time, were never seriously considered for the Nobel Prize, whereas Lewis and O'Neill and Pearl Buck all received the prize in a single decade. Or the religious study that young French writers devoted to Faulkner, young English writers to Hemingway, young German writers before the war to Thomas Wolfe, young Russian writers first to Dos Passos then to Hemingway. Or the printing of "The Moon is Down" by the French underground, while "The Grapes 
of Wrath" was being published in Germany as anti-American propaganda. But I should think the chapter might be expanded ... to a consideration of the interaction between European and American literature - American literature freed by Europe in the years after I9I0 ... and European literature looking for freedom to American literature in the years after I933; the wave of American exiles to Europe being replaced by a wave of European literary exiles to America, with New York becoming for a time the center of free literature in the world. ${ }^{37}$

Undertaking to write on the impact of American literature abroad, Cowley entered a virtually uncharted field. He enlisted the help of his former boss at the Office of Facts and Figures, Archibald MacLeish, then Assistant Secretary of State,,$^{38}$ and collected first-hand information from Upton Sinclair, Margaret Mitchell, Pearl S. Buck, Sinclair Lewis, Jean Paul Sartre and a wide range of publishers, scholars and authors from Europe and Japan. If his letter to Spiller was Euro-centrically tinged, his chapter cast a worldwide net: it discussed the reception and resonance of modern American literature in England, France, Germany, Scandinavia, Italy, Russia, Latin America, Japan, China and India. It was not limited to canonical authors, but included popular and bestselling literature: after all, Cowley wrote contentiously to Spiller, Margaret Mitchell's Gone With the Wind was a much better book than most critics acknowledged and 'almost a phenomenon of nature in its sweep over the world', and Uncle Tom's Cabin was possibly better than Melville's White-Jacket or Stephen Crane's Maggie, a Girl of the Streets. ${ }^{39}$

It seems ironic that Cowley, with his scepticism about the nationalist ethos underlying the volume, should be asked to place the crown on the celebration of a national American literature. His conclusions, unsurprisingly, were cautious and restrained. The international status of American literature, he observed, had changed dramatically between I900 and I940: from a mere 'department' of English literature it had grown into 'one of the major living world literatures', and its contemporary literature was regarded in many countries as 'the greatest of them all'. Yet this new status was at best a 'secondary' consequence of the growth in economic and military power of the U.S., Cowley maintained, and to an important degree 'an independent development that testified to a change in the literature itself'. Cowley also pointed up the relativity of a national canon: 'Crossing the oceans is still a means by which the historian can step back and gain perspective'. When American 
writers were measured by the standards of other countries, each country appeared to have its own canon of American writing: 'the history of American books abroad has as many local variations as there are civilized countries'. And the writers most read and appreciated abroad were often different from those most highly esteemed by American critics: in Latin America Waldo Frank was rated very highly, and across the globe Upton Sinclair was the most widely translated American author. The international perspective, Cowley concluded, gave a new impression not only of the kaleidoscopic variety of American literature, but of its underlying unity. Seen from abroad, American writers had a family resemblance not always noticeable at home: 'American', a French critic told Cowley, 'is not so much a nationality as a style'..$^{40}$

Despite his scepticism, Cowley still shared in the broad nationalistic consensus underlying the LHUS. A national literature, he believed, could serve to cement the national culture, because of its essentially mythopoeic function: it could humanize and make inhabitable a strange continent through the creation of myths and legends - a notion that accorded with, perhaps even anticipated, the Myth and Symbol school in American Studies. 'A country without myths is a country naked of human associations in which we are intruders, not residents', Cowley wrote to his friend Kenneth Burke on 9 December I948. Nineteenthcentury American writers, in particular, had sought to create a national mythology, believing that 'a house has to be a little haunted before we can feel at home in it' ${ }^{41}$ Myths, in literature and in 'the popular mind', gave Americans 'a sense of community and common destinies' and made it possible to "believe in ourselves as characters in the drama of American history'. ${ }^{42}$ In this respect, Cowley observed in a June 1947 lecture at Syracuse University, literature was not narrowly nationalistic but could transcend national or racial difference and parochialism: '[The good writer] has the power to broaden our imaginative scope; to make us feel, for example, that Frenchmen are not mere Frogs, or Italians Wops, or colored persons niggers; that all of us are part of a brotherhood that is bigger than national or racial boundaries'. ${ }^{43}$

\section{The Boomerang of the Past}

By I949, the year he was elected to the National Institute of Arts and Letters, Cowley enjoyed recognition as an authoritative literary critic 
and cultural historian. But despite his successful professional rehabilitation, his radical political past came back like a boomerang, intensifying his guilt-laden struggle to come to terms with the past and worries about minimizing damage to his income and his reputation. 1949 proved a year of personal anxiety, as a number of events, broadly publicized in national and local newspapers, served to bring his fellowtravelling past back into the limelight. In the winter and early spring of I949 Cowley, who had served as advisor and director of the artists' colony Yaddo since the early I930s, was reluctantly drawn into the notorious 'Lowell affair', when several guests, including Robert Lowell and Elizabeth Hardwick, accused director Elizabeth Ames, a close friend of Communist Agnes Smedley, of having been 'somehow deeply and mysteriously involved' in subversive activities. ${ }^{44}$ In June and December Cowley was summoned to testify in the widely publicized Alger Hiss trials. And in the winter of that year he became the unwanted subject of public political controversy, when his appointment to Walker Ames guest lecturer at the University of Washington in Seattle was fought by reactionary forces in the state. ${ }^{45}$

Cowley's endeavours on behalf of 'the making of American literature' thus took place in a sharply intensifying reactionary political climate of Cold War threat and anti-Communist witch-hunting. Though his radicalism had subsided, he held strong political opinions, but felt effectively gagged by public restrictions on what could be debated openly. Like many, he resorted to an uneasy compromise, keeping politically quiet, while - in private correspondence, or working behind the scenes - seeking to fan opposition to conformity, orthodoxy and a hysterical pro-Americanism. That same critical year of I 949 Cowley went to work for Viking Press, and from his new position fostered the publication of 'honest and thoughtful' books like Alan Barth's The Loyalty of Free Men (195I) and Granville Hicks's account of his conversion to and disillusionment with Communism, Where We Came Out (I954). Uncomfortable at remaining silent, yet hesitant to speak out unequivocally, he tried to move with caution and diplomacy, but was not always able to avoid prevarication. ${ }^{46}$

Cowley's career in the late I940s and early I950s illustrates the complex interaction of personal history and sensibility with the political and cultural exigencies of the moment. On the one hand the era imposed strict limitations on whoever was critical of the dominant Cold 
War ideology; on the other, it left room for commitment and moral perseverance. For many, as for Cowley, it meant a precarious balancing act between courage and compromise. Cowley's involvement with Perspectives USA illuminates the ambiguities endemic to literature and politics in the early Cold War years.

\section{Cowley and Perspectives USA}

Despite his unease over the domestic situation, Cowley was excited by a proposal from James Laughlin to launch a new quarterly aimed to promote the best of American literature and culture abroad. As publisher of New Directions Laughlin was an influential mediator of European and Latin American writers, hospitable to against-the-grain modernists like Ezra Pound, William Carlos Willams, Delmore Schwartz and Kenneth Rexroth. ${ }^{47} \mathrm{He}$ had published Cowley's second book of poetry, The Dry Season (I94I), and both men had discussed the possibility of reissuing Cowley's Exile's Return (I934) $4^{48}$ and his translation of Valéry's Variety (I927). On 23 November I95 I Laughlin wrote to fathom Cowley's interest, enclosing a four-page 'Proposal for a Quarterly Magazine on American Materials for Distribution Abroad'.

As appears from the proposal, the magazine, soon entitled Perspectives USA, was to be published in four languages (English, French [Profils], German [Perspektiven] and Italian [Prospetti] - originally also in Spanish and Russian) and aimed to promote a view of American culture as at least as highbrow and distinguished as the best of Europe:

The Project. To publish abroad in translation in various foreign language editions a quarterly that would fairly represent the best American writing and thinking on the highest level.

The Purpose. To promote peace by increasing respect for America's non-materialistic achievements among intellectuals abroad. At present, America's cultural standard is judged by such popularized media as Hollywood movies, certain popular magazines in the mass field, etc., which arouse the derision and contempt of foreign intellectuals and students, creating an attitude which contributes to the concept of America as a commercial imperialist. Because of currency restrictions America's best magazines 
cannot reach foreign readers. Exchange concessions are used abroad chiefly for the purchase of American scientific and technical books. ${ }^{49}$

Explicitly geared towards Europe, the magazine was to avoid politics and eschew overt propaganda (the embers of anti-Americanism, especially among left-wing European intellectuals, were not to be fanned), to steer clear of advertising ('Not even for Fords!', Laughlin spoke) ${ }^{50}$ and to focus on the spread of American literature, philosophy and the arts:

Scope. The contents should avoid science ... and politics. Literary criticism, poetry, creative prose, short plays, and philosophical speculation should be the backbone, with collateral emphasis on the arts. Within three years an issue should be devoted to "advance guard," writing to which Europe is keenly sensitive. Historical theory of the non-controversial kind. No propaganda for the "American Way" etc. Reproductions of serious American art to the extent which the budget will permit. Reviews of important new U.S. books and selective bibliographies on subjects treated..$^{51}$

Though the magazine was to be supervised by a managing editor James Laughlin, with assistance from poet and Poetry editor Hayden Carruth $^{52}$ - it was also anxious to present 'varying points of view' and 'avoid cultism'. To this purpose a system of 'rotating editors' was devised, at a honorarium of $\$ 2500$ per issue, so as to attract 'the best available talent'. The guest editors would be chosen 'for their liveliness of mind rather than their academic responsibility. They should be "creative critics" with minds which are not too specialized, to bring out the relationships between collateral fields'. The quality of translations was of special concern, but, the proposal speculated: 'Fortunately the exodus of scholars and literary men from Europe has provided a large pool of competent translators in this country'. ${ }^{53}$ The polylingual Edouard Roditi supervised translations; Alvin Lustig was in charge of layout and cover design. ${ }^{54}$

The new magazine, sponsored by the Ford Foundation, was envisioned to correct a widespread European perception of American culture as shallow, imperialist and steeped in commercialism. Following Laughlin's personal predilections, it focused on modern and modernist American literature, with 'collateral emphasis' on the arts, architecture and music, as proof of America's high cultural achievement. 
But its presentation of modernism also fitted in what Barnhisel termed 'the Cold War modernist project' - the use of 'modernism' as the preferred cultural diplomatic vehicle for exporting American ideology and democracy - in that it transformed modernism from the rebellious, anti-bourgeois oppositional movement it had been in the early decades of the twentieth century, into 'an affirmation of Western bourgeois liberal values' which were considered to be 'integral' to America and which, like NATO and the Marshall Plan, 'served to knit the West together, with the United States leading the way'. ${ }^{55}$ To this purpose Perspectives USA 'depoliticized and aestheticized modernism, presenting it ... as the natural product of free individualist artists exercising free inquiry and free expression in a free society'. ${ }^{56}$

Perspectives USA was launched in February $\mathrm{I} 952$ when the Ford Foundation allocated $\$ 500,000$ to the founding of Intercultural Publications, Incorporated (IPI), with the express aim to publish a magazine that, as Laughlin put it in the first issue, would enable readers 'to view the culture of the United States in accurate perspective' ${ }^{57}$ Ford Foundation president Paul Hoffman was a former Marshall Plan administrator, and the project fitted seamlessly into the foundation's new orientation towards impacting the foreign arena. ${ }^{8}$ The Ford Foundation, as Barnhisel has demonstrated, was deeply invested in U.S. Cold War cultural diplomacy, its self-proclaimed mission being to 'strengthen democratic values, reduce poverty and injustice, promote international cooperation, and advance human achievement' ${ }^{59}$ Its mission led it to sponsor programs such as the Salzburg Seminar in American Studies, and to use 'culture as a weapon' to advance a representation of American culture as the product of an individual freedom of expression possible under democratic capitalism but precluded under conditions of Soviet Communism. ${ }^{60}$ In Perspectives USA such aims were presented covertly, in seemingly non-political terms: as a note 'to the reader' in each of its sixteen issues put it: 'The [Ford] Foundation is dedicated to works of philanthropy, social welfare, and education throughout the world. It is one of the objectives of The Ford Foundation to further friendship and understanding among the peoples of all countries through the exchange of cultural materials'.

Given Cowley's internationalist bent, his background in publishing and magazine editing, his broad approach to literature, and his practice of writing for the highbrow intellectual and the general reader, it is easy 
to see why Laughlin invited Cowley to guest-edit the fifth, Autumn I953 issue of Perspectives USA $;^{61}$ he also asked him to join the project's Advisory Board. Other guest-editors included James Laughlin (the pilot issue, October I952), Lionel Trilling (issue 2), Jacques Barzun (issue 3), R.P. Blackmur (issue 6) and the philosopher Irwin Feldman (issue 7). From issue 8 on the cumbersome system of rotating editors was abandoned, Laughlin in effect presiding over the remaining issues. ${ }^{62}$

The issue edited by Cowley is an illuminating case study, for the way the magazine functioned as an instrument of U.S. cultural diplomacy, for its presentation of Cold War modernism, and for the ways it reveals Cowley's ambivalent commitment to its underlying aims. On 8 December I95I Cowley had responded to Laughlin's proposal for Perspectives USA by listing the 'several reasons why it seems to me useful and exciting':

The great reason is, of course, that the public in other countries gets a false impression of American life and literature from such exports of ours as movies, hard-boiled detective stories, comic books and magazines in which there is more advertising than text. Much or most of the serious work that is being done here is still unknown in Europe. Some of it was revealed in the American number of Fontaine, published in Algiers during the war. ${ }^{63}$ The immense effect of that one issue of one magazine - which led, among other things, to new French translations of most of the authors who appeared in it - suggests how much could be accomplished by a well edited quarterly appearing in several languages.

But, Cowley reasoned, the magazine would also have a beneficial effect on the domestic literary scene, where periodicals and the book industry were facing a financial crisis: even if not published in the U.S., Perspectives still would improve economic prospects for American writers, and give them the professional encouragement that 'comes from the assurance that some of their best work was being read and discussed in all countries'. ${ }^{64}$

Within days of Laughlin's invitation Cowley set to work, tapping into his vast network of literary acquaintance and writing to close literary friends he was eager to see represented: Conrad Aiken, Kenneth Burke, John Cheever and Edmund Wilson. Burke was Cowley's oldest and closest friend; Wilson had been his predecessor critic-editor on The New Republic; and both Aiken (whom he had known since his 
days at Harvard) and Cheever (whom he had launched on his writer's career by publishing his very first story in The New Republic in 1930) were American writers whom Cowley had long felt deserved greater recognition - and remuneration. But he also felt doubtful of aiding and abetting an enterprise that, for all Laughlin's intent to eschew propaganda for 'the American Way', ${ }^{65}$ inescapably smacked of the jingoism Cowley had rejected earlier. On 2 I March I952, he wrote to Burke:

A new job for Papa Cowley. Editing one issue of a magazine dreamed up by Jay Laughlin and backed by the Ford Foundation ... High-toned national propaganda (and what are you doing in that galley, Mr. C?). Idea behind the magazine is that foreigners get a bellyful of slick and popular American writing, but don't learn enough about serious American art, philosophy, literature - hence Perspectives USA will be a sort of show window of what various great editors consider to be our best work. ... Obviously an issue of such a magazine is a chance to do something good. It might even be a chance to do something new, although on that point I'm more skeptical ...66

Writing to Wilson a day later, he was more explicitly sceptical: 'I consented to edit an issue of [Perspectives USA]. I don't like the business of spending money to exhibit serious American writing to foreigners, when it would be more useful to exhibit serious foreign writing to Americans, to jolt us out of the self-satisfied world provinciality into which we are sinking' ${ }^{67}$ Cowley's reservations proved prescient, and dovetailed with what George Kennan would argue four years later: the principal reason why Americans needed cultural contacts with people from other nations, Kennan advanced in I956, lay precisely 'in our own need as Americans for just this sort of enrichment of our national spirit' ${ }^{68}$ To counteract the U.S. tendency towards 'self-satisfied world provinciality' and avoid an impression of propaganda, Cowley invited a critic from France (where anti-American sentiment was perhaps strongest among left-wing intellectuals), ${ }^{69}$ Mll. Claude-Edmonde Magny, author of a prize-winning critical study on contemporary American fiction, L'age du roman américaine (I949), to write about John Steinbeck's latest novel, East of Eden (I952).

But Cowley also aimed to branch out into a wider cultural realm, following the guidelines in the official press release for the journal: 'Perspectives USA will present significant American writing and art, with attention as well to music, the theater, architecture, philosophy 
and creative scholarship'. ${ }^{70}$ For 'philosophy and creative scholarship' Cowley relied on Kenneth Burke's 'Antony in Behalf of the Play', in which Julius Caesar's Antony steps out of role to address the audience about the play he is in. For suggestions on American music Cowley wrote to Quincy Porter and Marc Blitzstein, but finally settled on a piece on Bix Beiderbecke by Otis Ferguson, the former jazz and movie critic for The New Republic, who had died in military service in Italy in I943, and whom Cowley was eager to save from oblivion. In theatre he invited Harold Clurman, one of the founders of the Group Theater (I93 I-4I) and until recently drama critic for The New Republic (I94852), to review the current state of American theatre. And in architecture he enlisted Hugh Morrison, author of several studies on contemporary architecture, to write on the new tendencies in domestic American architecture. Morrison's essay, 'American Houses: Modern Style', offered 'a picture of one of the better sides of our culture', ${ }^{71}$ Cowley thought, and would be 'fascinating to foreign readers': 'I think the recent changes in domestic architecture really indicate the rebirth of the American family as a living institution - twenty years ago the house (or apartment, rather) was chiefly a place to sleep, and the cook or maid was the real center of the house'. ${ }^{72}$ Morrison's emphasis on the 'modern' single-family home was perfectly in tune with Perspectives' aim to win the hearts and minds of Europeans for the American way of life, and highlighted the triumph of pragmatic individualism over the collectivist architectural aesthetics popular in the Soviet Union. ${ }^{73}$

In the field of contemporary American writing Cowley faced an embarrassment of riches. Over the spring and summer of 1952, he variously considered reprinting an essay on Hemingway by John Peale Bishop from After the Genteel Tradition ( I937); short stories by William Goyen (whom he considered one of the most promising young writers, and much appreciated in Europe) and Eudora Welty ('The Bride of the Innisfallen'); a play by the Armenian-American writer William Saroyan; a humorous piece by New Yorker writer Joseph Mitchell ('Fascism Comes to Black Ankle County'), and one on Greenwich Village by Milton Klonsky. In the end, all of these were discarded (for reasons varying from length to unavailability), and Cowley made alternative choices: for Bishop's essay he chose a more recent essay by psychologist Henry Murray on Conrad Aiken; to represent one of the young new voices in fiction, he selected a debut story from Sewanee Review by 
Richard Gay, 'Isham Street', hoping that, with John Cheever's 'Torch Song', it might preclude an overemphasis on criticism. He also included a sociological essay (from Antioch Review) on issues of consumerist lifestyle and leisure in the new American suburb by David Riesman, author of The Lonely Crowd (1950) - 'one of the most stimulating books I [have] read for ages', as Cowley told Riesman on I May I953. ${ }^{74}$

The issue edited by Cowley remained predominantly literary - even modernist - in focus, but it reflected his predilection for the broadly contextual and interdisciplinary approach of American Studies rather than the more narrowly textual and formalist focus of the New Criticism. Cowley's choices thus mirrored his personal creative and critical preferences, even as they largely dovetailed with the ideological purposes of the project. A more detailed discussion of the issue's contents might illuminate to what extent these reflected or waylaid such aims, but here it seems more pertinent to consider the question: what, if any, were the parameters of ideological or cultural-diplomatic constraint within which Cowley, and Laughlin, were permitted to operate?

Despite his scepticism at supporting an endeavour at 'hightoned national propaganda', Cowley saw enough benefit in the venture to put his shoulders under it - including, perhaps, the $\$ 2500$ editorial fee, attractive for an independent freelance writer who stood in danger of losing income under the blacklisting practices of McCarthy. Both Cowley and Laughlin, in effect, were sensitive to the possibility of conservative backlash on the domestic or anti-American backlash on the international front. Laughlin was adamant, even inflexibly so, to avoid anything overtly political ${ }^{75}$ and was determined to remain "culturally neutral' ${ }^{\prime} 6$ in the commitment of Intercultural Publications, Inc., to international cultural exchange: it was the place of Perspectives USA, he observed, 'to keep out of the political fight, to think of the field of culture as one where people of opposed ideologies can still meet on friendly ground and learn to respect each other as human beings'. ${ }^{77}$ Yet, according to Hayden Carruth, he was 'scared to death' that he, or Intercultural Publications, Inc., might be accused of 'communist leanings' and called to testify before HUAC..$^{8}$ To Dwight Macdonald Laughlin insisted that 'no pressure of any kind has ever been exerted' and that "where we have avoided articles which gave a very gloomy picture of conditions here, we have not attempted to do a sugar-coating job'. On the contrary, he insisted, the magazine contained 'all kinds of 
frank references to the deficiencies existing here'. ${ }^{79}$ In practice, such pronouncements proved somewhat disingenuous.

Given Cowley's former political affiliations and their recent public resurgence, Laughlin might understandably have felt a degree of unease about his guest editor. Cowley, in turn, was aware of the necessity of walking a thin line between downright openness about America's 'deficiencies' and the need to present an image of its culture's high level and distinct richness. Thus, when Wilson suggested he might include a sampling from his Three Reliques of Ancient Western Poetry. Collected By Edmund Wilson from the Ruins of the Twentieth Century (I95I), a privately printed pamphlet sent out as Christmas greetings and containing a scathing critique of the current political and religious climate, Cowley pointed up the limits of his editorial freedom: 'For Wilson's Reliques I would be impugned and incarcerated by the Ford Foundation. They would be less afraid of Karl Marx than of unkind words about the one Church. Especially at a time when all the foundations are going to be investigated by Congressman [Edward E.] Cox. I'm waiting for the day when nothing can be printed here without a congressional or episcopal imprimatur'.$^{80}$

Writing to Laughlin about Claude-Edmonde Magny's review of Steinbeck, Cowley revealed how he moved, had to move, with circumspectness:

When you read the French draft you'll note a somewhat anti-American crack in the next-to-last sentence of the article. I think it should stand in French, to satisfy the author and to give French readers the notion that Perspectives isn't a propaganda magazine, but I'm wondering whether I shouldn't delete it from the English version (from which the German and Italian versions should be made). ${ }^{81}$

Magny's review of East of Eden insightfully discussed the novel's strengths and weaknesses, but also offered a covert cultural critique of America and its 'deficiencies'. Unlike European novelists (Thomas Mann, Marcel Proust) American writers had largely averted facing the nation's problematical past, she charged: 'If we judged America by its best novelists, with the exception of Faulkner, we might be tempted to believe that it was entirely occupied with living in and thinking about the present'. America's 'violent separation' from the Old World and 
'the systematic destruction of the native tribes acted as a sort of "block" in the collective consciousness', she advanced, and this deficiency extended into American ethics and morality. It was 'a sign of the unstable position of American novelists', she wrote in her next-to-last sentence, that ' $[\mathrm{t}]$ heir work might tempt us to believe that the whole country was refusing to achieve a full consciousness of good and evil' ${ }^{82}$ So much, the insidious implication seemed to be, for America's claim to moral and political leadership in the world. The article, which appeared in the small-print back pages of the issue, passed muster.

Cowley's willingness to compromise with the magazine's - and the Foundation's - guidelines was put to the test when Laughlin, belying the flexibility he had affirmed to Macdonald, proved quite strict in vetoing articles that too overtly presented a negative image of American culture. The essay by Harold Clurman, which Cowley had especially commissioned - and approved - for his issue, proved a case in point. On 8 December I952 Laughlin wrote to Cowley from Switzerland that he was 'troubled' by Clurman's 'negative picture' of the current American theatre situation:

there are just dozens of Communist critics waiting to pick up something like that and splash all over the headlines of their literary papers, making capital out of the fact that an American writer has admitted in an American magazine for circulation abroad that the American theatre suffers terribly from American materialism. I can just see what they would make of it now, and the hot water we would be in with the Trustees when report of it got home. ${ }^{83}$

Cowley was incensed but responded temperately:

I was deeply disturbed by your letter about the Clurman article - all the more so because it was a complete surprise to me. I had been keeping in mind the special problems of Perspectives in selecting material for the issue and had dropped some stories and articles from consideration because of the impression they might give in Europe. But I hadn't been worried by the Clurman article. Everybody knows the New York theatre is in a bad situation that is getting worse. Clurman is telling the simple truth about it and I have always gone on the principle that the truth, even if painful, is in the long run the best argument for our side. 
Laughlin's estimate that Clurman's relatively mild criticism would produce 'an unfortunate impression in Europe' was 'a real shock', Cowley confessed, and put 'a limitation on us that is straighter than I had expected'. Clurman, he persisted, had 'written a general survey of the American theatre - playhouses, playwrights, production, actors - with good and bad things to say about everything but the financial set-up'. With some emendations, he hoped, the article could still be retained and so help to give 'a broader cultural base to the issue ... ${ }^{84}$ Laughlin discussed the issue at the Ford Foundation, but in January reported a definitive no, and Cowley could not but capitulate, if grudgingly. Clurman's article was dropped from the issue, and American theatre was not represented in the issue.

Cowley's altercation with Laughlin over Clurman's essay also roused concern about his own editorial introduction, on the American literary situation anno I953:

I started to write about the new generation of American novelists and ... I found that my conclusions were essentially negative and perhaps not for export, in view of what you say about the Clurman piece. I'll go to work again on the editorial next week and ... think about its more hopeful aspects too, which can be mentioned without departing from the candid truth. ${ }^{85}$

Perhaps as a result, Cowley's editorial on the state of American literature was marked by caution and restraint bordering on the deflationary. 'In the United States today', he observed, 'fiction and poetry seem to be standing still' ${ }^{86}$ Rather than experiment with new forms, writers had 'consolidate[d] positions already reached by the more daring of their predecessors' and 'the new developments have been chiefly in the field of criticism'. The level of critical writing was impressively high and technically accomplished, yet he felt uneasy that the so-called 'newer' or 'ontological' critics tended to forego a work's sources and social or moral effects to confine themselves to 'the work as a separate entity with its own laws of being ${ }^{87}$ Though we appeared to be 'living in an Alexandrian age of lowered creative vigor', the prevailing atmosphere was one of 'excitement, vitality, combativeness', with 'new methods' of analysis and 'new values' being discovered.$^{88}$ The new critics had importantly helped to establish a 'classic' past for American literature, but there were signs that 'the fields [they have been mining] are 
beginning to be exhausted - "corned out", as they say in Kentucky of river-bottom land where one crop of maize has followed another'. What the critics needed, were 'new novels, new poems, new dramas of sufficient density and distinction to justify [their] close and prolonged analysis' ${ }^{89}$ Scanning the horizon for the new writers - some represented in his issue of Perspectives USA - that could lift American literature out of its present 'interval or interregnum', Cowley made a - somewhat strained - effort to end his essay on a hopeful note:

Mere talent is relatively common; it is conviction and character that are needed. The result is a fluid situation in which the influence of a single great writer [as Hemingway and Faulkner had been] might prove to be decisive ... If such another great writer appears and is recognized, the lesser but talented writers surrounding him will arrange themselves into a new configuration, like iron filings around a magnet, and perhaps we shall have another great period in American writing..$^{90}$

Cowley's introductory essay for Perspectives was the overture to a new book, published in I954 as The Literary Situation, in which he expressed himself with more vigour and acrimony about the timidity of the new novelists and the limitations of the new critics. Cowley's estimate that contemporary writers of the I950s were still writing in the 'fading' mode of modernism, but producing work that was distinctly inferior to that of their great predecessors, was in line with the larger cultural mood, and the verdicts expressed by critics like Stephen Spender in Encounter. ${ }^{91}$ His essay for Perspectives - wilfully balanced, restrained in its critique, and forcedly hopeful about the prospects for American culture - seemed a somewhat Procrustean effort to fit himself within the magazine's underlying premises of Cold War cultural diplomacy. Pace Magny's covert criticism of America's deficiencies, and pace Cowley's personal scepticism, the contents of the issue, too - with one essay on suburban family lifestyle and leisure, one on domestic architecture, and one celebrating jazz - served implicitly as advertisements for the American way of life that might win the hearts and minds of Europeans. The conspicuous absence of politics or any references to the Cold War anxieties on the domestic front experienced by Cowley himself also fit into Laughlin's policy - the absence of politics in itself served a political purpose. The selection of stories and poems, too, 
confirms Barnhisel's argument that by viewing literature as a separate non-political realm it could be made to serve the ends of cultural diplomacy. By the I950s, as Barnhisel argues and Cowley's introductory essay confirms, modernism had lost its once revolutionary and avantgarde force and become the property of an elitist literary establishment of academics and new critics - it had become a style rather than a mode of subversive criticism, depoliticized, aestheticized and domesticated, a mode of literature and art 'defanged' 92 and made safe for middle-class consumption, and the ultimate expression of individual freedom and creativity. Hence, 'redefined and made safe for official sponsorship', ${ }^{93}$ it could be used as a weapon in the cultural Cold War, an instrument to advocate 'the superiority of American egalitarianism and meritocracy' over Soviet collectivism and totalitarianism. ${ }^{94}$

\section{Notes}

I For example, the appraisals of Cowley by Warren I. Susman, Culture as History (New York, I984) and Morris Dickstein, Double Agent: The Critic and Society (New York, Oxford, I992).

2 Alfred Kazin, Starting Out in the Thirties (Boston, I965) I6.

3 In 1940 the owners of The New Republic, Dorothy and Leonard Elmhirst, growing impatient with the magazine's tardiness in moving towards interventionism, reorganized the editorial staff and Cowley (ironically the editor who was earliest in championing U.S. intervention) was demoted to leading book reviewer, a position he held until I944. See my 'Gazing East: Malcolm Cowley, The New Republic and the Path to War, I939-194I', Daniela Rossini (ed.), From Theodore Roosevelt to FDR: Internationalism and Isolationism in American Foreign Policy (Keele, I995) I47-84.

4 Frances Stonor Saunders, The Cultural Cold War: The CIA and the World of Arts and Letters (New York, 2000).

5 Greg Barnhisel, Cold War Modernists: Art, Literature, and American Cultural Diplomacy (New York, 2015).

6 Cowley to James M. Kempf, 23 November I974, in Hans Bak (ed.), The Long Voyage: Selected Letters of Malcolm Cowley, 1915-1987 (Cambridge, 2014) 646.

7 Nancy F. Cott, 'Revisiting the Transatlantic I920s: Vincent Sheean vs. Malcolm Cowley', American Historical Review I I8 (2013) 46-75. 
8 Kristin L. Matthews, Reading America: Citizenship, Democracy, and Cold War Literature (Amherst, Boston, 20 16); Barnhisel, Cold War Modernists.

9 Qtd. in Matthews, Reading America, I I.

Io Matthews, Reading America, Io-I I.

I I Ibid., I3.

I2 Qtd. in Matthews, Reading America, 3.

I3 For example, Malcolm Cowley, 'Reading in Wartime', New Republic CVII ( I4 September I942) 32 I-2.

I4 Cf. Matthews, Reading America, 2 I, 23.

I5 Bak (ed.), The Long Voyage, 476. See also Malcolm Cowley, 'Some Dangers to American Writing', New Republic CXXXI (22 November I954) I I4-7. Reprinted in Malcolm Cowley, The Flower and the Leaf: A Contemporary Record of American Writing Since I94I. Edited by Donald W. Faulkner (New York, I985) I I 2-8.

I6 Trysh Travis, 'The Man of Letters and the Literary Business: Re-viewing Malcolm Cowley', Journal of Modern Literature 25:2 (Winter 2001/2002) 2.

I7 Cowley, 'Some Dangers to American Writing'.

I 8 Travis, 'The Man of Letters and the Literary Business', 7-8.

I9 Ibid., 8-Io.

20 Ibid., Io.

2 I Malcolm Cowley, 'America the So Beautiful', New Republic CVII (2 August 1942) I22-3.

22 Malcolm Cowley, A Many-Windowed House: Collected Essays on American Writers and American Writing (Carbondale, Edwardsville, I970) 202.

23 Bak (ed.), The Long Voyage, 348.

24 Malcolm Cowley, 'Introduction', The Portable Hemingway (New York, I944) vii-xxiv.

25 http://www.nobelprize.org/nobel_prizes/literature/laureates/I 949/ faulkner-speech.html, accessed 28 June 2017.

26 Malcolm Cowley, A Second Flowering: Works and Days of the Lost Generation (New York, I973) I49.

27 Lawrence H. Schwartz, Creating Faulkner's Reputation: The Politics of Modern Literary Criticism (Knoxville, I988).

28 Cf. Barnhisel, Cold War Modernists, I24-33.

29 See Cowley's objections to Schwartz's thesis of 'conspiracy' in his letter to Schwartz of 29 October I980, in Bak (ed.), The Long Voyage, 678-9.

30 Tremaine McDowell, American Studies (Minneapolis, I948) 32.

3 I Ibid., 9I-2. 
32 Ibid., 93.

33 Robert E. Spiller, 'History of a History', in idem, Milestones in American Literary History (Westport, I977) I I I-28.

34 Alfred Kazin, On Native Grounds (New York, I942) 488.

35 Malcolm Cowley, 'Hemingway's Wound - And Its Consequences for American Literature', in Donald Faulker (ed.), The Portable Malcolm Cowley (New York, I990) 432.

36 Besides 'American Books Abroad', Cowley contributed 'How Writers Lived' and, co-authored with Henry Seidel Canby, 'Creating an Audience'.

37 Bak (ed.), The Long Voyage, 364.

38 For MacLeish's role in Cold War cultural diplomacy, see Barnhisel, Cold War Modernists, I5-7.

39 Cowley to Spiller, 4 May I946, Malcolm Cowley Papers, The Newberry Library, Chicago; Cowley to Spiller, 5 August I946, Bak (ed.), Long Voyage, 366-7.

40 Malcolm Cowley, 'American Books Abroad', in Robert E. Spiller et al. (eds), Literary History of the United States (New York, I948) I374-9I.

4I Bak (ed.), The Long Voyage, 390-9I.

42 Malcolm Cowley, 'Three Cycles of Myth in American Writing', in idem, $A$ Many-Windowed House, 229-43.

43 Bak (ed.), The Long Voyage, 378.

44 Cowley reported at length on the affair in letters to Granville Hicks, Allen Tate and Ernest Hemingway. See Bak (ed.), The Long Voyage, 399-405.

45 For a more detailed account, see Cowley's letters to Robert B. Heilman and Harry Post, of the New Milford Times, in Bak (ed.), The Long Voyage, 4I2-7.

46 For Cowley's engagement with the complex interactions of literature and politics between I949 and I954, see Bak (ed.), The Long Voyage, 396-463.

47 Ian S. MacNiven, "Literchoor Is My Beat" A Life of James Laughlin, Publisher of New Directions (New York, 20I4).

48 Exile's Return was reissued in I95I, in a revised and expanded edition, by Cowley's new publisher, Viking Press. See Cowley to Marshall Best, I6 November I949, in Bak (ed.), The Long Voyage, 426-7.

49 'Proposal for a Quarterly Magazine on American Materials for Distribution Abroad', I. Malcolm Cowley Papers. Also cf. Greg Barnhisel, Cold War Modernists, I86-7.

50 MacNiven, “Literchoor Is My Beat”, 28I.

5I 'Proposal', 2. 
52 Carruth was the magazine's 'project administrator' for its first four issues. By the time Cowley came to edit the fifth (Autumn I953) issue, Carruth had been demoted to 'editoral consultant'. Barnhisel, Cold War Modernists, 192.

53 'Proposal', I-4.

54 MacNiven, "Literchoor Is My Beat", 282.

55 Ibid., I I.

56 Ibid., I79.

57 Ibid., I 88; the quote from Laughlin appears on page I93. Also cf. Greg Barnhisel, 'Perspectives USA and the Cultural Cold War: Modernism in Service of the State', Modernism/modernity I4:4 (November 2007) 739 .

58 MacIven, "Literchoor Is My Beat", 280.

59 Quoted in Barnhisel, Cold War Modernists, I84.

6o Ibid., I85. For Barnhisel's larger argument, see his Cold War Modernists, in particular the Introduction and Chapter I, 'Freedom, Individualism, Modernism'.

6I Laughlin to Cowley, 6 March I952, Malcolm Cowley Papers.

62 'The first issue of Perspectives USA appeared in October 1952 in a print run of 32,586 for all five editions: approximately 3,000 for the United States, I I,Ooo in England, 7,000 in France, 8,000 in Germany, 3,500 in Italy. After three issues of Perspectives USA, demand justified a print run of 50,000, ... the numerical high point of the journal'. The journal was distributed in 52 countries, at 35 cents an issue in Europe, \$I.50 in the U.S.; MacIven, "Literchoor Is My Beat", 286.

63 Fontaine was a French journal edited by Max-Pol Fouchet and published during the occupation in Algiers. It became the voice of French Resistance poetry in North Africa. Fontaine 27/28 (June/July I944) celebrated a galaxy of mostly modernist American writers and poets. It was republished in Paris in 1945 .

64 Cowley to Laughlin, 8 December i95I, Bak (ed.), The Long Voyage, 447-8.

65 Cf. Barnhisel, Cold War Modernists, I87-8.

66 Cowley to Burke, 2I March 1952, Malcolm Cowley Papers.

67 Cowley to Edmund Wilson, 22 March I952, Edmund Wilson Papers, Yale Collection of American Literature, Beinecke Rare Books and Manuscripts Library, Yale University.

68 George Kennan, 'International Exchange in the Arts', Perspectives USA I6 (Summer I956) 9-I4. Quoted in Barnhisel, Cold War Modernists, 2 I 5. 
69 Richard F. Kuisel, Seducing the French: The Dilemma of Americanization (Berkeley, Los Angeles, London, I993).

70 Quoted in Barnhisel, Cold War Modernists, I 88.

7 I Cowley to Laughlin, Io September I952, Malcolm Cowley Papers.

72 Cowley to Hugh Morrison, 6 September I952, Malcolm Cowley Papers.

73 Cf. Barnhisel, Cold War Modernists, 204.

74 Bak (ed.), The Long Voyage, 457.

75 Barnhisel, Cold War Modernists, 207.

76 MacIven, “Literchoor Is My Beat”, 288.

77 Quoted in Barnhisel, Cold War Modernists, 209.

78 MacIven, “Literchoor Is My Beat”, 288.

79 Quoted in Barnhisel, Cold War Modernists, 209.

80 Cowley to Wilson, Io April I952, Malcolm Cowley Papers. Cowley included a review by Wilson of the letters of Theodore Roosevelt instead.

8I Cowley to Laughlin, Io September I952, Malcolm Cowley Papers.

82 Claude-Edmonde Magny, 'Review of East of Eden', Perspectives USA 5 (Fall I953) I46-52.

83 Laughlin to Cowley, 8 December I952, Malcolm Cowley Papers.

84 Cowley to Laughlin, I3 December I952, Malcolm Cowley Papers.

85 Ibid.

86 Malcolm Cowley, 'The Literary Situation: I953', Perspectives USA 5 (Fall I953) 5 .

87 Ibid., 6, 8.

88 Ibid., 9 .

89 Ibid., I I.

90 Ibid., I3.

9I Cf. Barnhisel, Cold War Modernists, 23, I70.

92 Ibid., I 84.

93 Barnhisel, 'Perspectives USA and the Cultural Cold War', 730.

94 Ibid., 73I.

\section{About the Author}

Hans Bak, emeritus professor of American literature and American Studies at Radboud University, the Netherlands, is the author of Malcolm Cowley: The Formative Years (University of Georgia Press, I993) and editor of The Long Voyage: Selected Letters of Malcolm 
Cowley, 1915-1987 (Harvard University Press, 2014). He is now writing a biography of Malcolm Cowley. Bak has published in European and American journals on mostly twentieth-century American and Canadian fiction, drama, biography, multiculturalism and American Studies. Subjects include Tim O'Brien, David Rabe, Louise Erdrich, Gerald Vizenor, James Welch, Sherman Alexie, LeAnne Howe, ChangRae Lee, Bharati Mukherjee, Carol Shields, Wayne Johnston, Michael Ondaatje, Lawrence Hill, Tomson Highway and Alex Colville. His research interests include contemporary American and Canadian fiction (Native American/ First Nations literatures); instruments of culture (American publishers and periodicals, American 'middlemen' of letters); and the reception of American literature and culture in Europe in a comparative, transnational perspective. E-mail: h.bak@ let.ru.nl 